\title{
Kontekstualisasi Pendayagunaan Zakat di Badan Amil Zakat Nasional (Baznas) Kota Pekanbaru Berdasarkan Undang-Undang Nomor 23 Tahun 2011 Tentang Pengelolaan Zakat
}

\author{
Yeni Triana \\ Universitas Lancang Kuning, Jl. Yos Sudarso, Km. 8 Rumbai, Pekanbaru, Riau \\ (0761) 54092/yenitriana@gmail.com \\ Hasan Basri \\ Universitas Lancang Kuning, Jl. Yos Sudarso, Km. 8 Rumbai, Pekanbaru, Riau \\ (0761) 54092/hasan_basri@yahoo.com \\ Muhammad Azani \\ Universitas Lancang Kuning, Jl. Yos Sudarso, Km. 8 Rumbai, Pekanbaru, Riau \\ (0761) 54092/mhd.azani@unilak.ac.id
}

\begin{abstract}
Article 27 Paragraph (1) and (2) Law of 23 Year 2011 on management of zakat states that zakat can be empowered for the weak economic community. This article discusses contextualization, contextualization efforts, obstacles and efforts to overcome the constraints of the contextualization of utilization of zakat in Baznas Pekanbaru City based on Law of 232011 on Zakat Management. The results showed that the contextualization of utilization of zakat in Baznas Pekanbaru City is ijtihad conducted by amil zakat in an effort to increase the prosperity of mustahik zakat into muzaki. Article 27 Paragraph (1) and Paragraph (2) above make no clear mention of appropriate models, patterns and mechanisms regarding the utilization of zakat in the sense of empowerment, so that the contextualization ijtihad conducted by Baznas Pekanbaru City is very different from the pattern of zakat utilization in the other region. Contextualization effort is an effort to change the mindset of zakat mustahik from consumptive to be productive in accordance with the purpose of substance of zakat. These efforts should be followed with appropriate and appropriate targeted patterns of community empowerment. Contextualization efforts should have a roadmap (roadmap) as a guide for the implementation of zakat utilization. The Strategy conducted by Baznas Pekanbaru City in carrying out the above efforts is to development zakat community based or zakat community development. Obstacles and efforts to be done in overcoming these barriers are, first, the lack of public awareness in zakat, thus, its lack understanding should be overcomed by increasing the socialization of true rule (fiqh) of zakat. Second, the lack of qualified human resources should be overcomed by increasing the well understanding of zakat for amil zakat, its management, and its empowerment. Third, the inadequate barriers about zakat information systems have resulted in unintegrated of the mustahik and muzaki


database, that is why, it should be complemented with the updated integration of zakat management information system.

Keywords: Contextualization of utilization of zakat; muzaki; mustahik zakat

\begin{abstract}
Abstrak
Pasal 27 Ayat (1) dan (2) Undang-Undang Nomor 23 Tahun 2011 tentang pengelolaan zakat menyatakan bahwa zakat dapat diberdayakan untuk masyarakat ekonomi lemah. Analisis artikel ini membahas kontekstualisasi, upaya kontekstualisasi, hambatan dan upaya mengatasi hambatan kontekstualisasi pendayagunaan zakat di Baznas Kota Pekanbaru berdasarkan Undang-Undang Nomor 23 Tahun 2011 tentang Pengeloalaan Zakat. Hasil penelitian menunjukkan bahwa kontekstualisasi pendayagunaan zakat di Baznas Kota Pekanbaru merupakan ijtihad yang dilakukan oleh amil zakat dalam upaya peningkatan kesejahteraan mustahik zakat menjadi muzaki. Pasal 27 Ayat (1) dan Ayat (2) di atas tidak menyebutkan secara tegas model, pola, dan mekanisme yang tepat terkait pendayagunaan zakat dalam pengertian pemberdayaan, sehingga ijtihad kontekstualisasi yang dilakukan oleh Baznas Kota Pekanbaru sangat mungkin berbeda dengan pola pendayagunaan zakat di daerah lain. Upaya kontekstualisasi merupakan upaya merubah pola pikir mustahik zakat dari konsumtif menjadi produktif sesuai dengan tujuan substansi zakat. Upaya ini harus dikuti dengan polapola pemberdayaan masyarakat yang tepat guna dan tepat sasaran. Upaya kontekstualisasi harus memiliki peta jalan (roadmap) sebagai panduan pelaksanaan pendayagunaan zakat. Strategi Baznas Kota Pekanbaru dalam melaksanakan upaya di atas dengan melakukan pengembangan komunitas berbasis zakat atau zakat community development. Hambatan dan upaya yang harus dilakukan dalam mengatasi hambatan tersebut di antaranya, pertama, hambatan rendahnya kesadaran masyarakat dalam berzakat bagi muzaki dan pemahaman mustahik zakat secara parsial harus diatasi dengan peningkatan sosialisasi bagi muzaki dan mustahik zakat. Kedua, hambatan tentang minimnya sumber daya manusia yang berkualitas harus diatasi dengan adanya peningkatan kualitas pemahaman fikih zakat bagi amil zakat dan tata kelola pendayagunaan dan pemberdayaan zakat. Ketiga, hambatan tentang sistem informasi zakat yang belum memadai berakibat data base mustahik dan muzaki belum terintegrasi, harus diatasi dengan pembaruan sistem informasi pengelolaan zakat yang terintegrasi.
\end{abstract}

Kata Kunci: Kontekstualisasi pendayagunaan zakat; muzaki; mustahik zakat

\title{
A. PENDAHULUAN
}

Pasal 27 Ayat (1) dan (2) Undang-Undang Nomor 23 Tahun 2011 tentang pengelolaan zakat menyatakan bahwa zakat dapat diberdayakan untuk masyarakat ekonomi lemah. Kategori masyarakat dengan ekonomi lemah disebut dengan mustahik zakat. Pemberdayaan dalam konteks pendayagunaan zakat sebagai 
amanah dari pasal di atas bertujuan mengangkat derajat kelompok lemah menjadi kelompok yang mendiri secara ekonomi.

Para ahli hukum Islam kontemporer berijtihad bahwa dana zakat sebaiknya dapat digunakan untuk kepentingan yang memiliki nilai manfaat besar bagi kesejahteraan umat (Qaradhawi, 1997: 112). Efektivitas pemberdayaan zakat untuk usaha produktif, terkait erat dengan posisi dan peran amil. Sesuai dengan perkembangan kontemporer, peran amil zakat bukan hanya sebatas pengumpulan, pengelolaan, dan pendistribusian zakat untuk aspek konsumtif, melainkan juga telah merambah kepada upaya pemberdayaan zakat untuk usaha-usaha produktif dalam peningkatan kesejahteraan umat (Permono, 2005: 101).

Dalam Pasal 33 Peraturan Meteri Agama Nomor 52 Tahun 2014 tentang syarat dan tata cara penghitungan zakat mal dan zakat fitrah serta pendagaunaan zakat untuk usaha produktif menyatakan bahwa pendayaguaan zakat dapat dilaksanakan apabila kebutuhan dasar mustahik telah terpenuhi, menghasilkan nilai tambah bagi mustahik, dan mustahik berdomisili di wilayah lembaga pengelola zakat. Pemanfaatan dana zakat secara produktif dapat menciptakan kesejahteraan secara individu atau kelompok mustahik dan pada gilirannya ia akan berubah status menjadi muzaki (Hafidhuddin, 2007: 107). sedangkan pemanfaatan dana zakat secara konsumtif, dana itu akan habis seketika. Padahal tujuan pemanfaatan dana zakat dalam hukum Islam lebih mengarah kepada konsep produktif itu (Galuh, 2012: 234).

Pasal 9 Peraturan Daerah (Perda) Zakat Provinsi Riau menakankan skala prioritas pada mustahik zakat dengan fokus pada pemberian zakat konsumtif, setelah itu terpenuhi dapat ditingkatkan menjadi zakat produktif. Dalam praktiknya, pendayagunaan dana zakat yang diberikan kepada mustahik zakat ternyata mengalami berbagai kesulitan, karena pada umumnya mustahik zakat adalah kelompok masyarakat yang belum terbiasa dengan program pengembangan dana produktif. Selama ini mustahik zakat lebih menyukai program zakat konsumtif (wawancara dengan Yusrialis, Agustus, 2017).

Kontekstualisasi pendayagunaan zakat merupakan tantangan yang harus dihadapi oleh amil zakat yang menjadi pengelola Badan Amil Zakat Nasional (Baznas) Kota Pekanbaru. Tantangan menjadi sulit karena tipologi mustahik zakat yang dikelola oleh Baznas Kota Pekanbaru belum terbiasa dengan pendayagunaan zakat yang bersifat produktif dan berorientasi nilai tambah. Hanya sebagian mustahik zakat yang bersedia menjadi mustahik zakat yang produktif.

Dalam Pasal 27 Ayat (1) dan (2) Undang-Undang Nomor 23 Tahun 2011 di atas tidak diatur secara tegas tentang pola, mekanisme, stratetgi, dan metode pendayagunaan zakat yang harus dilaksanakan oleh amil zakat. Pasal ini memberikan peluang kepada amil zakat untuk melakukan kontekstualisasi pendayagunaan zakat dengan semangat peningkatan kesejahteraan masyarakat. Setiap Baznas di setiap daerah tampaknya dapat mengembangkan pola, mekanisme, 
stratetgi, dan metode pendayagunaan zakat yang menyasar objek masyarakat ekonomi lemah dalam kelompok mustahik zakat.

Berdasarkan data yang dirilis oleh Baznas Kota Pekanbaru menyebutkan bahwa jumlah mustahik zakat yang telah mendapat distribusi dana zakat adalah sebanyak 1213 (seribu dua ratus tiga belas) mustahik. Data mustahik memperoleh bantuan tersebar pada semua kecamatan di Kota Pekanbaru yang didistribusikan pada dana zakat konsumtif, biaya pendidikan, biaya pengobatan, modal usaha dan sebagainya. Jenis pekerjaan mustahik zakat meliputi berbagai jenis pekerjaan seperti penjual gorengan, tukang jahit, dan jenis ragam pekerjaan lainnya maupun mustahik zakat yang tidak bekerja.

Beberapa analisis dalam studi yang pernah dilakukan menemukan korelasi positif antara pengelolaan zakat produktif dengan peningkatan kesejahteraan masyarakat. Hanya saja beberapa studi tersebut belum memberikan pernyataan yang tegas terkait hasil pendayagunaan zakat yang dapat diterapkan pada semua situasi dan kondisi yang dihadapi oleh amil zakat pada setiap Baznas. Analisis dalam artikel ini menfokuskan pada upaya kontekstualisasi yang dilaksanakan oleh Baznas Kota Pekanbaru dalam pendayagunaan zakat untuk memenuhi amanat pada Undang-Undang Nomor 23 Tahun 2011.

Rumusan masalah dalam artikel ini difokuskan pada: 1) bagamana kontekstualisasi pendayagunaan zakat di Baznas Kota Pekanbaru berdasarkan Undang-Undang Nomor 23 Tahun 2011 tentang Pengeloalaan Zakat? 2) bagaimana upaya kontekstualisasi pendayaguanaan zakat sebagai bentuk kemandirian mustahik zakat? dan 3) Bagaimana hambatan dan upaya mengatas hambatan kontekstualisasi pendayagunaan zakat di Baznas Kota Pekanbaru berdasarkan Undang-Undang Nomor 23 Tahun 2011 tentang Pengeloalaan Zakat? Tujuan analisis dalam studi ini untuk mengetahui kontekstualisasi pendayagunaan zakat di Baznas Kota Pekanbaru dalam rangka peningkatan kesejahteraan mustahik zakat.

\section{B. METODE PENELITIAN}

Jenis penelitian adalah penelitian hukum sosiologis yang membahas berlakunya hukum positif tentang kontekstualisasi pendayagunaan zakat di Baznas Kota Pekanbaru berdasarkan Undang-Undang Nomor 23 Tahun 2011 Tentang Pengelolaan Zakat. Lokasi penelitian dilaksanakan di Baznas Kota Pekanbaru sebagai tempat pengumpulan data dari wawancara, beberapa perpustakaan di Kota Pekanbaru, dan beberapa kecamatan yang dipilih untuk mengumpulkan data lapangan dari mustahik zakat.

Sumber data terdiri atas data primer, sekunder, dan tersier. Data primer diperoleh dari wawancara dengan pengelola Baznas di Kota Pekanbaru dan mustahik zakat. Pengelola Baznas yang diwawancarai adalah Yusrialis selaku Kepala Pelaksana Baznas, Muhammad Azmi selaku ketua bidang pemberdayaan Baznas, dan Syahrudin selaku anggota Divisi Pemberdayaan Baznas, sedangkan 
mustahik yang diwawancarai adalah mustahik yang memperoleh bantuan modal usaha atau bantuan dalam bentuk program. Data sekunder diperoleh dari bahan hukum primer, artikel ilmiah yang dipublikasikan dalam jurnal dan laporan-laporan hasil penelitian baik yang telah dipublikasikan atau yang belum terpublikasi. Artikel ilmiah yang digunakan sebagai sumber acuan terbaru pada jurnal-jurnal ilmiah bereputasi, diantaranya Journal of Islamic Monetary Economic and Finance Tahun 2016, American Journal of Economic Tahun 2016, International Journal of Education and Research Tahun 2016, dan International Journal of Zakat Tahun 2017. Data tersier berupa Kamus hukum dan kamus Besar Bahasa Indonesia (KBBI).

Teknik pengumpulan data dilakukan dengan melakukan observasi, kajian pustaka, dan wawancara. Observasi bertujuan untuk mengetahui adanya kesenjangan antara teori dan praktik dalam pendayagunaan zakat, terutama untuk mengetahui pola kontekstualisasi yang dapat menjadi ciri khas pada pemberdayaan zakat di Baznas Kota Pekanbaru. Observasi dilakukan di Baznas Kota Pekanbaru, dan Kecamatan Rumbai Pesisir karena mustahik zakat yang memperoleh bantuan dana zakat dalam bentuk program berada pada kecamatan ini. Dalam memperkuat hasil observasi, penelitian ini juga melakukan studi kepustakaan untuk mendalami kerangka konseptual kontekstualisasi pendayagunaan zakat sebagai basis teori. Seluruh data primer diperoleh dari wawancara dengan responden baik di Baznas Kota Pekanbaru, mustahik zakat di Kecamatan Sukajadi, Kecamatan Rumbai Pesisir, dan Kecamatan Rumbai. Wawancara menggunakan pola tersetruktur dan nonstruktur. Pola terstruktur menggunakan daftar pertanyaan yang disampaikan kepada responden, kemudian responden memberikan jawaban secara langsung atau menulis sediri dalam jawaban setiap pertanyaan, sedangkan nonstruktur dilakukan wawancara tanpa menggunakan daftar pertanyaan yang lebih banyak saat mewawancarai mustahik zakat. Responden yang tidak dapat diwawancarai dengan tatap muka, wawancara dilaksanakan dengan menggunakan telpon atau dapat menuliskan jawaban lewat email.

Analisis data menggunakan metode induktif dengan menarik kesimpulan dari pernyataan yang bersifat khusus ke dalam pernyataan yang bersifat umum. Langkah-langkah analisis data adalah dengan melakukan verifikasi data dari responden, data-data yang telah diverifikasi dilakukan kategorisasi berdasarkan kebutuhan data pada pembahasan terutama data kualitatif dan data kuantitatif, hasil kategorisasi data disusun dalam pembahasan yang dipadukan dengan berbagai data kepustakaan baik dari jurnal ilmiah dan dari berbagai peraturan-peraturan tentang zakat. Temuan-temuan dalam setiap analisis data merupakan perpaduan data lapangan dan kepustakaan yang dijadikan hasil analisis dalam pembahasan. Hasilhasil temuan yang berbeda dengan studi yang telah ada sebelumnya merupakan hasil analisis yang dapat dipertanggungjawabkan secara ilmiah. 


\section{PEMBAHASAN}

1. Kontekstualisasi pendayagunaan zakat di Baznas Kota Pekanbaru berdasarkan Undang-Undang Nomor 23 Tahun 2011 tentang Pengeloalaan Zakat

Kontekstualisasi pendayagunaan zakat yang dilakukan oleh lembagalembaga zakat, termasuk Baznas Kota Pekanbaru merupakan fenomena yang sedang populer saat ini (Miftah, 2008: 247). Kerangka teori yang digunakan dalam kontekstualisasi adalah konsep maqasid syariah (tujuan hukum syariah) dan maslahah mursalah (teori kemaslahatan). Dalam pendekatan maqasid syariah, syariah dipandang sebagai sekumpulan aturan yang diletakkan pada suatu tujuan hukum dalam 5 (lima) tujuan utama-primer, yaitu: 1) perlindungan agama; 2) jiwa; 3) akal; 4) harta; dan (5) perlindungan kehormatan atau keturunan. Tujuan-tujuan ini kemudian diformulasikan lagi dalam tingkatan yang lebih rendah, yakni tujuan sekunder (hâjjiyyāt) dan tujuan pelengkap-tersier atau taḥsinniyyāt (Idris, 1997: 71).

Kontektualisasi pendayagunaan zakat merupakan persoalan yang terkait dengan tujuan syari at dan kemaslahatan hidup umat Islam. Pendayagunaan zakat bagi usaha produktif dapat memaksimalkan tujuan dan fungsi zakat bagi umat Islam, terutama dalam aspek pengembangan ekonomi dan kesejahteraan. Kesuksesan pendayagunaan zakat untuk usaha produktif sangat bergantung pada kerja keras, keterampilan dan profesionalitas amil. Dalam praktiknya, Baznas Kota Pekanbaru menggunakan 2 (dua) cara dalam pemberian dana zakat untuk usaha produktif: 1) pemberian dana zakat dalam bentuk uang kepada pedagang kecil yang telah memiliki usaha; dan 2) pemberian modal usaha kepada mustahik zakat yang dapat mengembangkan usaha secara produktif dalam kontkes Zakat Community Development (Hikam, 2008: 317).

Ancas Sulchantifa Pribadi menyimpulkan bahwa aspek pendayagunaan zakat untuk usaha produktif, telah relevan dengan tujuan (maqâshid) syariah dan pandangan mayoritas ahli hukum Islam. Hanya saja dalam praktik pendayagunaan zakat, para amil zakat tidak seragam dalam penetapan besarnya prosentase dana zakat yang digunakan untuk usaha produktif (Pribadi, 2006: 27). Pengembangan pendayagunaan zakat di Baznas Kota Pekanbaru telah mengarah pada pemberdayaan komunitas pada Kecamatan Rumbai Pesisir. Hanya saja program ini termasuk program yang dalam tahap rintisan dan akan dijadikan sebagai model dalam pengembangan pendayagunaan zakat. Pengelola Baznas telah berupaya menata sistem organsisasi dan manajemen pengelolaan zakat yang masih bertaraf klasikal, bersifat konsumtif dan terkesan inefisiensi, sehingga kurang berdampak sosial yang berarti (wawancara dengan Yusrialis, Agustus, 2017). 
Berdasarkan data yang rilis Badan Pusat Statistik (BPS) Kota Pekanbaru telah menetapkan Garis kemiskinan dan penduduk miskin tahun 2012-2016 (Badan Pusat Statistik (BPS) Kota Pekanbaru, 2017: 158):

Tabel 1. Garis kemiskinan dan penduduk miskin tahun 2012-2016

\begin{tabular}{lccc}
\hline Tahun & Garis Kemiskinan (Rp) & \multicolumn{2}{c}{ Penduduk Miskin } \\
\cline { 3 - 4 } & & Jumlah (Jiwa) & Persentase \\
\hline 2012 & 357200 & 32.700 & 3.38 \\
2013 & 381287 & 32.500 & 3.27 \\
2014 & 399451 & 32.290 & 3.17 \\
2015 & 416479 & 33.760 & 3.27 \\
2016 & 435082 & 32.490 & 3.03
\end{tabular}

BPS Kota Pekanbaru menetapkan garis kemiskinan pada taraf yang berbedabeda setiap tahun. Garis kemiskinan tahun 2016 berkisar Rp 435.082 (empat ratus tiga puluh lima ribu delapan puluh dua rupiah). Penduduk miskin dalam jumlah sebanyak 32.490 atau 3.03 persen. Data BPS ini dapat disandingkan dengan data Basnas Kota Pekanbaru memilah kategori fakir dan miskin, meskipun dalam data BPS tidak dikenal istilah fakir.

\section{a. Penentuan kelompok mustahik zakat sebagai penerima zakat produktif dalam rangka kontekstualisasi pendayagunaan zakat}

Baznas Kota Pekanbaru mengacu kepada QS. at-Taubah: 60 yang menyatakan bahwa mustahik zakat ada 8 (delapan). Ahli hukum Islam Ibn al-Qayyìm al-Jauziyah berijtihad bahwa 8 (delapan) kelompok penerima zakat dapat dikelompokkan kepada 2 (dua) kelompok. Pertama, kelompok penerima zakat yang mengambil zakat karena kebutuhan yang mendesak, kelemahan dan sedikit banyaknya kebutuhan. Kelompok ini adalah fakir, miskin, budak dan ibn al-sabîl. Kedua, kelompok yang mengambil bagian zakat berdasarkan kemanfaatan, yakni para petugas zakat (amil), muallaf, ghârim dan fi sabîlillah (Qaradhawi, 1994: 186).

Masdar Farid Mas'udi menyarankan bahwa pendayagunaan zakat diperlukan perhatian terhadap 2 (dua) aspek. Pertama, setiap dana zakat yang dipungut dari tangan muzaki harus didayagunakan dan diprioritaskan kepaada orang-orang lemah secara ekonomi. Kedua, dana zakat maupun non zakat (pajak- Farid termasuk yang setuju terhadap penyamaan pajak dan zakat) adalah amanat 
Tuhan untuk kepentingan masyarakat. Oleh karena itu, pertanggungjawaban harus relevan dengan pertanggungjawaban secara moral-spritiual kepada Tuhan, atau secara formal kepada masyarakat sekaligus. Pertanggungjawaban formal kepada masyarakat dapat diartikan sebagai badannya, sedangkan pertanggungjawaban moral-spiritual kepada Tuhan adalah ruh dan jiwanya (Mas'udi, 1993: 184).

Dalam upaya pendayagunaan zakat yang lebih efektif, Baznas Kota Pekanbaru melakukan pemilahan terhadap kebutuhan mustahik zakat berdasarkan permohonan yang diajukan kepada Baznas. Mustahik zakat dapat dikelompokkan pada program Pekanbaru Cerdas, Pekanbaru Makmur, Pekanbaru Sehat, Pekanbaru Peduli, dan Pekanbaru Takwa. Jumlah distribusi dana zakat pada setiap program tersebut berbeda-beda, sesuai dengan kebutuhan mustahik zakat. Program ini diperuntukkan bagi mustahik zakat di seluruh kecamatan di Kota Pekanbaru. Selain itu, program Pekanbaru Makmur mengarah pada pengembangan komunitas berbasis zakat (Zakat Community Development).

\section{b. Pendistribusian dana zakat di Baznas Kota Pekanbaru}

Pendistribusian dana zakat diberikan kepada kelompok mustahik pada 2 (dua) kelompok. Pertama, kelompok mustahiq fakir, miskin, amil dan muallaf merupakan kelompok penerima zakat yang dapat diprioritaskan, tidak ada syarat dan kewajiban apapun yang berkaitan dengan penerimaan zakat, termasuk mengembalikan dana zakat. Kedua, kelompok ghārimīn, riqāb, ibn al-sabīl dan fi sabilillah, dalam hal penerimaan mereka terkait dengan beberapa persyaratan (Qaradhawi, 1994: 186). Baznas Kota Pekanbaru lebih cenderung pada kelompok yang pertama dalam pendistribusian zakat. Kecenderungan ini tampak dari pendistribusian pada 5 (lima) program yang telah di tetapkan di atas.

Berdasarkan data yang dirilis oleh Divisi Pemberdayaan Zakat Baznas Kota Pekanbaru dana zakat telah didistribusikan pada 5 (lima) program. Masing-masing program memperoleh alokasi distribusi dana zakat yang berbeda. Jumlah dana pada setiap dapat dilihat dalam table berikut:

Tabel 2. Alokasi dana zakat dalam setiap program

\begin{tabular}{llr}
\hline No & \multicolumn{1}{c}{ Nama Program } & Jumlah (Rp) \\
\hline 1 & Pekanbaru Cerdas & Rp 359.000.000,00 \\
2 & Pekanbaru Makmur & Rp 754.800.000,00 \\
3 & Pekanbaru Sehat & Rp 25.500.000,00 \\
4 & Pekanbaru Peduli & Rp 1.198.675.000,00
\end{tabular}


Penyaluran dana zakat pada 5 (lima) program di atas berbeda disesuaikan dengan kebutuhan pada saat pembagian distribusi zakat. Pebedaan tersebut mengacu pada prioritas pada salah satu program pada saat itu. Pada periode $2016 / 2017$, jumlah alokasi dana zakat lebih banyak pada program Pekanbaru Peduli sebesar Rp 1.198.675.000,00 (satu milyar seratus Sembilan puluh delapan enam ratus tujuh puluh lima ribu rupiah), sedangkan program Pekanbaru Takwa menerima distribusi sebesar Rp 11.700.000,00 (sebelas juta tuju ratus ribu rupiah) dan program Pekanbaru Sehat menerima distribusi dana zakat sebesar Rp 25.500.000,00 (dua puluh lima juta lima ratus ribu rupiah).

Program Pekanbaru Makmur adalah program yang diperuntukkan bagi mustahik zakat untuk memperoleh bantuan untuk zakat produktif. Seluruh usaha yang memiliki nilai produktif dapat mengajukan bantuan program ini. Program ini bagian dari ijtihad para amil di Baznas Kota Pekanbaru sebagai bentuk kontekstualisasi pendayagunaan zakat (wawancara dengan Yusrialis, Agustus, 2017). Hanya saja saat ini, pendayagunaan zakat belum dapat menyentuh seluruh mustahik zakat yang ada di Kota Pekanbaru. Dalam rangka kontekstualisasi pendayagunaan zakat, Baznas Kota Pekanbaru sedang mencanangkan Zakat Community Development (ZCD) di Kecamatan Rumbai Pesisir. Pelaksanaan ZCD masih dalam tahap percobaan, meskipun telah dimulai sejak 2 (dua) tahun yang lalu. Program Pekanbaru Makmur menerima distribusi dana zakat sebesar Rp 754.800.000,00 (tujuh ratus lima puluh empat juta delapan ratus ribu rupiah).

Program Pekanbaru sehat diperuntukkan bagi mustahik zakat yang membutuhkan bantuan pembiayaan. Pengajuan bantuan program ini harus menyertakan surat keterangan dari rumah sakit dan termasuk kategori mustahik zakat yang terdaftar di Baznas Kota Pekanbaru. Jumlah alokasi dana zakat pada program ini sebesar Rp 359.000.000,00 (tiga ratus lima puluh Sembilan juta rupiah).

Perbandingan distribusi dana zakat untuk 5 (lima) program di Baznas Kota Pekanbaru dapat dilihat dalam gambar berikut: 
Gambar 1. Distribusi dana zakat pada setiap program

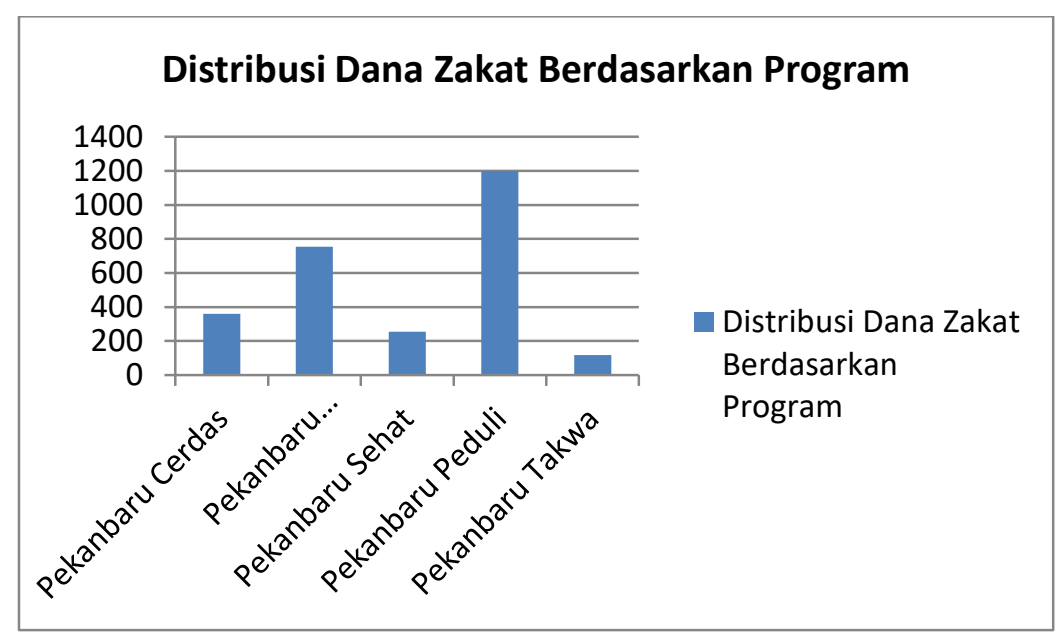

Data distribusi dana zakat pada setiap kecamatan menunjukkan bahwa seluruh kecamatan di Kota Pekanbaru menerima alokasi dana zakat. Setiap kecamatan memperoleh distribusi dana zakat berbeda-beda. Mustahik zakat di Kecamatan Tenayan Raya termasuk menerima dana zakat paling besar dibandingkan kecamatan lain sebesar Rp 336.650.000,00 (tiga ratus tiga puluh enam juta enam ratus lima puluh ribu rupiah), sedangkan mustahik di Kecamatan Sail menerima dana zakat sebesar Rp 59.750.000,00 (lima puluh Sembilan juta tujuh ratus lima puluh ribu rupiah). Kecamatan Sail menerima distribusi dana zakat paling kecil dibandingkan dengan kecamatan yang lain di Kota Pekanbaru. Perbandingan distribusi dana zakat di setiap kecamatan tercantum dalam table berikut ini:

Tabel 3. Distribusi dana zakat di setiap kecamatan bagi mustahik zakat

\begin{tabular}{lll}
\hline No & \multicolumn{1}{c}{ Kecamatan } & Jumlah (Rp) \\
\hline 1 & Bukit Raya & Rp 179.650.000,00 \\
2 & Payung Sekaki & Rp 103.200.000,00 \\
3 & Pekanbaru Kota & Rp 303.100.000,00 \\
4 & Lima Puluh & Rp 152. 150.000,00 \\
5 & Tenayan Raya & Rp 336.650.000,00 \\
6 & Marpoyan Damai & Rp 275.250.000,00 \\
7 & Tampan & Rp 242.100.000,00
\end{tabular}




$\begin{array}{cl}8 & \text { Sukajadi } \\ 9 & \text { Sail } \\ 10 & \text { Senapelan } \\ 11 & \text { Rumbai } \\ 12 & \text { Rumbai Pesisir }\end{array}$

Rp 274.450.000,00

Rp 59.750.000,00

Rp 103.250.000,00

Rp 100.250.000,00

Rp 216.250.000,00

\section{Jumlah}

Baznas Kota Pekanbaru mengacu prinsip pada Pasal 33 Peraturan Menteri Agama RI Nomor 52 Tahun 2014 yang menyatakan bahwa mustahik harus berdomisili di wilayah kerja pengelola zakat. Prinsip pengutamaan pembagian zakat pada masyarakat setempat, yaitu masyarakat yang mendiami daerah (negara) tempat zakat tersebut dipungut. Pada Pasal 9 Peraturan Daerah (Perda) Nomor 2 Tahun 2009 menegaskan bahwa pendayagunaan zakat harus mengutamakan mustahik dalam masing-masing wilayah yang menjadi wilayah kerja amil zakat. Oleh karena itu, kontekstualisasi pendayagunaan zakat terhadap masyarakat pada negara tempat muzaki, dan mustahik berada (Qaradhawi, 1994: 186).

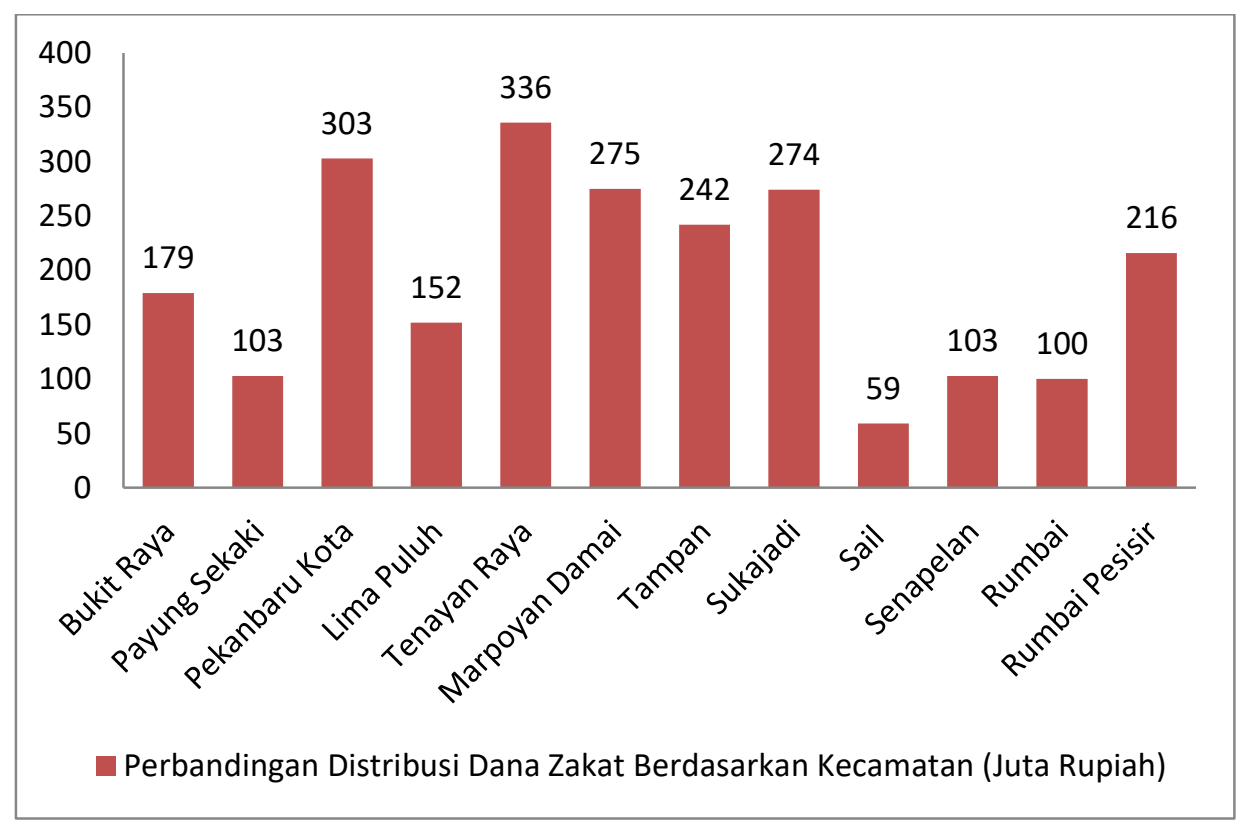

\section{c. Distribusi dana zakat kepada mustahik zakat dalam bentuk in cash dan in nature}

Zakat yang diserahterimakan kepada mustahik zakat dapat berupa in cash (uang tunai) atau in kind dalam bentuk program (Permono, 1995: 41). AlQuran tidak menjelaskan secara terperinci dan detail tentang teknis pendistribusian dan pendayagunaan zakat. Namun demikian, paparan al-Quran 
tentang delapan kelompok zakat yang meliputi fakir, miskin, 'āmil zakāt, muallaf, riqāb, ghārim, $f i$ sabīlillah dan ibnu al-sabīl sebagai prinsip pendayagunaan zakat yang harus dipedomani dan diimplementasikan oleh setiap pengelola dana zakat.

Pendayagunaan zakat dapat berpedoman pada penjelasan al-Quran yang dikontekstualisasikan saat ini: 1) Allah tidak menetapkan perbandingan yang tetap antara bagian masing-masing 8 (delapan) pokok alokasi (asnâf); 2) Allah tidak menetapkan delapan asnaf harus diberi semuanya, Allah hanya menetapkan zakat dibagikan kepada delapan asnâf, tidak boleh keluar daripada delapan asnāf; dan 3) Allah tidak menetapkan zakat harus dibagikan dengan segera setelah masa pungutan zakat. Selain itu, tidak ada ketentuan bahwa semua hasil pungutan zakat (baik sedikit maupun banyak) harus dibagikan semuanya (Qaradhawi, 1997: 112).

Ijtihad para ahli hukum Islam tentang di Baznas Kota Pekanbaru bersifat edukatif, produktif dan ekonomis, sehingga mustahik zakat menjadi wajib zakat pada tahun berikutnya. Selain itu, hasil pengumpulan zakat selama belum dibagikan kepada mustahiq dapat merupakan dana yang dapat dimanfaatkan bagi pengembangan program-program yang telah dicanangkan oleh Baznas Kota Pekanbaru (Wawancara dengan Muhammad Azmi, Juli 2017).

Baznas Kota Pekanbaru berpegang pada pendapat bahwa sistem distribusi termasuk mashlahat yang senantiasa berkembang sesuai perkembangan zaman. Sistem distribusi yang diterapkan Baznas itu merupakan tawaran yang sesuai dengan perkembangan sosial politik dan sosial ekonomi di Kota Pekanbaru. Praktik di Baznas itu sesuai dengan pandangan Muhammad Abu Zahrah (2001: 174-175) yang menyebutkan bahwa zakat adalah pembayaran yang layak untuk pembayaran bagi delapan kategori agar dapat membangun keadilan ekonomi dan keadilan sosial.

Pengelola pendayagunaan zakat Baznas Kota Pekanbaru mengidentifikasi fakir dan miskin dalam 2 (dua) bentuk, yaitu: 1) Fakir miskin yang mempunyai pekerjaan; dan 2) Fakir miskin yang tidak mempunyai pekerjaan. Untuk kelompok pertama, mereka diberi zakat untuk pekerjaannya atau sarana meningkatkan pekerjaannya baik yang nilai ekonomisnya kecil ataupun besar yang diukur menurut kebutuhan umum, sedangkan kelompok kedua, dapat diberikan dalam bentuk in cash (Wawancara dengan Muhammad Azmi, Juli 2017).

Program zakat produktif ekonomi lebih memungkinkan terwujudnya tujuan zakat secara lebih efektif di Kota Pekanbaru. Bentuk pendayagunaan zakat untuk usaha produktif bagi fakir miskin yang masih memiliki potensi untuk berusaha, dapat berupa antara lain: 1) memberikan modal usaha kepada mustahik zakat yang memiliki nilai berdaya; 2) membangun sarana prasarana pertanian dan perindustrian untuk menampung orang-orang miskin yang menganggur; dan 3) 
menyelenggarakan sentra-sentra pendidikan keterampilan dan kejuruan untuk mendidik para penganggur agar mereka memiliki keterampilan (skill) tertentu (Wawancara dengan Syahrudin, Juli 2017).

\section{Gambar 3.}

Tujuan zakat dalam bentuk in kind (program)

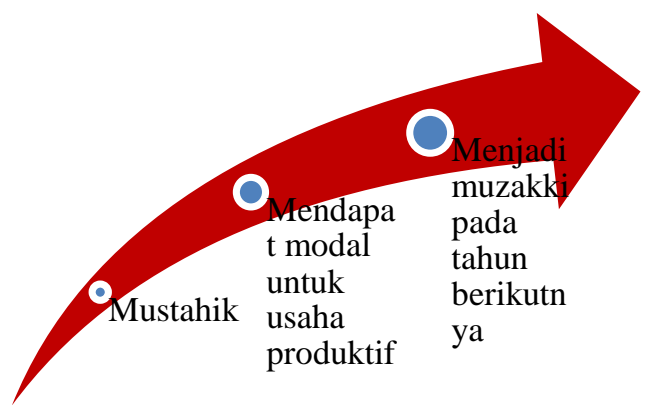

Baznas Kota Pekanbaru telah memperperluas cakupannya meliputi segala upaya produktif dan dikembangkan sebagai upaya pengentasan kemiskinan dan pemberdayaan ekonomi ummat. Dalam pelaksanaan operasionalnya harus mendapat dukungan secara multi dimensional, baik aspek politik, hukum, ekonomi dan budaya di Kota pekanbaru. Menurut Ketua Divisi Pemberdayaan Baznas Kota bahwa kemiskinan tidak hanya terbatas pada masalah ekonomi semata, tetapi sebagai persoalan multi aspek (Wawancara dengan Muhammad Azmi, Juli 2017).

\section{Upaya kontekstualisasi pendayaguanaan zakat sebagai bentuk kemandirian mustahik zakat}

Wujud konkret yang dilakukan Baznas kota Pekanbaru adalah dengan memberikan bantuan modal usaha kepada mustahik zakat. Sebelum modal diserahkan kepada yang berhak, Tim Pemberdayaan Baznas kota Pekanbaru melakukan studi kelayakan berupa survei tentang keadaan calon penerima bantuan, integritas moralnya, juga bidang apa yang patut diusahakan. Tujuannya dana itu dapat digunakan secara tepat dan benar untuk usaha-usaha produktif (Miftah, 2008: 116). Kemudian mustahik diberikan arahan dan motivasi agar mampu mengelola dana itu menjadi produktif. Program ini diharapkan penerima zakat (mustahik) dapat berubah menjadi pembayar zakat (muzakkī) di kemudian hari (Wawancara dengan Syahrudin, Juli 2017).

Baznas Kota Pekanbaru berusaha maksimal dalam mengembangkan pola pendayagunaan zakat. Ke depan tidak menutup kemungkinan bantuan dana zakat dalam bentuk alat-alat produksi, seperti mesin jahit, alat-alat pertanian, alat-alat pertukangan dan perbengkelan, juga dalam bentuk bibit dan binatang ternak (Wawancara dengan Muhammad Azmi, Juli 2017). Selain itu, dapat mendirikan unit-unit usaha yang langsung dikelola oleh lembaga amil zakat dengan melibatkan para profesional di bidangnya masing-masing, sementara para fakir 
miskin dipekerjakan dalam usaha tersebut sambil belajar mengelola. Posisi zakat bukan tujuan melainkan alat untuk mencapai keadilan sosial, mengentaskan kemiskinan dan memberdayakan ekonomi umat Islam di Kota Pekanbaru (Wawancara dengan Syahrudin, Juli 2017).

Kontekstualisasi pendayagunaan zakat yang dilakukan oleh Baznas Kota Pekanbaru dalam bentuk in kind merupakan upaya peningkatan ekonomi mustahik zakat secara berkesinambungan. Mustahik yang dinilai memiliki semangat berwirausaha diberikan modal usaha untuk mengembangkan usaha sesuai dengan minat mustahik. Hingga saat ini terdapat beberapa mustahik mendapat binaan dari Baznas Kota Pekanbaru sebagai berikut:

Tabel 3. Mustahik zakat binaan Baznas Kota Pekanbaru

\begin{tabular}{|c|c|c|c|}
\hline No & Jenis Usaha & Lokasi & Kondisi Usaha \\
\hline 1 & $\begin{array}{l}\text { Kelompok Kerajinan } \\
\text { Miniatur Bambu Motif } \\
\text { Melayu Lancang Kuning }\end{array}$ & Kec. Rumbai Pesisir & Lancar \\
\hline 2 & $\begin{array}{l}\text { Usaha Pot Bungan dan } \\
\text { Hias Bunga }\end{array}$ & Kec. Payung Sekaki & Lancar \\
\hline 3 & $\begin{array}{l}\text { Usaha Pengolahan Keripik } \\
\text { Tempe }\end{array}$ & Kec. Sail & Lancar \\
\hline 4 & Usaha Sol Sepatu & Kec. Bukit Raya & Lancar \\
\hline 5 & Pembinaan TPQ-OT & Kec. Rumbai Pesisir & Lancar \\
\hline 6 & $\begin{array}{l}\text { Kelompok Usaha } \\
\text { Kerajinan Tangan }\end{array}$ & Kec. Rumbai Pesisir & Lancar \\
\hline 7 & $\begin{array}{l}\text { Kelompok Usaha } \\
\text { Pertanian }\end{array}$ & Kec. Bukit Raya & Lancar \\
\hline 8 & $\begin{array}{l}\text { Pembinaan Anak Asuh } \\
\text { Baznas kota Pekanbaru }\end{array}$ & $\begin{array}{l}\text { Baznas Kota } \\
\text { Pekanbaru }\end{array}$ & Lancar \\
\hline 9 & Usaha harian berkah & Kec. Tampan & Lancar \\
\hline 10 & Usaha ternak bebek & Kec. Tenayan Raya & Lancar \\
\hline 11 & Usaha arang batok & $\begin{array}{ll}\text { Kec. } & \text { Kota } \\
\text { Pekanbaru }\end{array}$ & Lancar \\
\hline
\end{tabular}

Upaya kontekstualisasi merupakan upaya merubah pola pikir mustahik zakat dari konsumtif menjadi produktif sesuai dengan tujuan substansi zakat. Perubahan 
pola pikir mustahik zakat diikuti dengan semangat merubah prilaku menjadi produktif sebagai bagian dari upaya kontekstualisasi di Baznas Kota Pekanbaru. Dalam pandangan penulis, upaya ini harus dikuti dengan pola-pola pemberdayaan masyarakat yang tepat guna dan tepat sasaran. Upaya kontekstualisasi harus memiliki peta jalan (roadmap) sebagai panduan pelaksanaan pendayagunaan zakat.

Strategi Baznas Kota Pekanbaru dalam melaksanakan upaya di atas dengan melakukan pengembangan komunitas berbasis zakat atau zakat community development. Sebagai upaya awal, program ini akan difokuskan di Kecamatan Rumbai Pesisir Kota Pekanbaru. Berdasarkan keterangan Yusrialis, Kepala Pelaksana Badan Amil Zakat Nasional (Baznas) Kota Pekanbaru menyatakan bahwa Program ZCD diprioritaskan di Kecamatan Rumbai Pesisir. Hasil evalusi terhadap program pemberdayaan selama ini menunjukkan bahwa mustahik zakat di Kecamatan Rumbai lebih dapat diberdayakan dibandingkan dengan mustahik zakat di kecamatan lain di Kota Pekanbaru. Kecamatan Rumbai Pesisir ditetapkan sebagai pilot project (proyek percontohan) program ZCD (wawancara dengan Yusrialis, Agustus, 2017).

Gambar 3. Peta Kecamatan Rumbai Pesisir

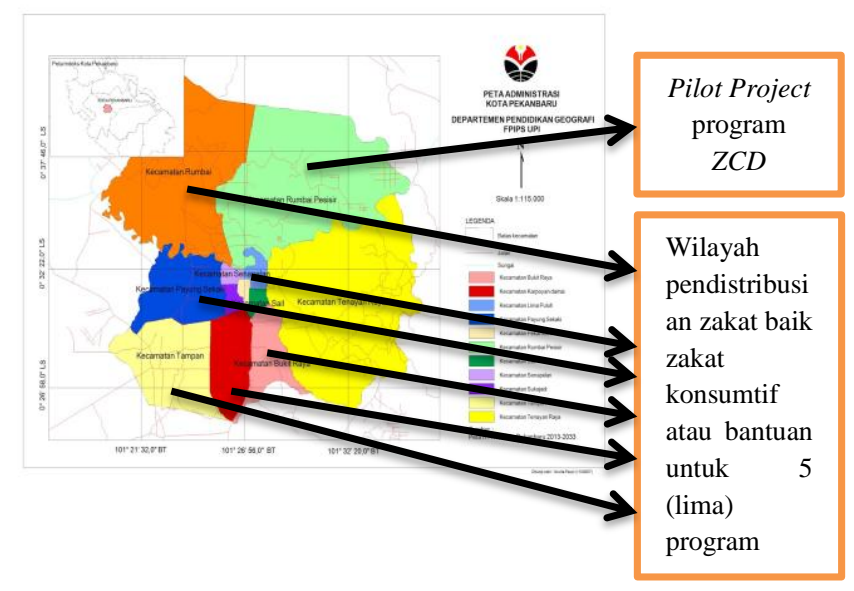

Alasan penetapan Kecamatan Rumbai Pesisir sebagai pilot project adalah berdasarkan hasil kajian terhadap tingkat keberhasilan mustahik zakat yang dilakukan pembianaan. Kategori mustahik yang berhasil adalah dapat meningkatkan penghasilannya setelah diberikan bantuan dana zakat. Bahkan diharapkan dapat meningkat statusnya menjadi muzaki. Mustahik zakat di Kecamatan Rumbai Pesisir termasuk mustahik zakat yang memiliki nilai berdaya yang kuat, relatif lebih dapat mengelola dana zakat produktif (wawancara dengan Yusrialis, Agustus, 2017).

\section{Hambatan dan Upaya Mengatasi kontekstualisasi pendayagunaan zakat}

Kontekstualisasi pendayagunaan zakat memiliki beberapa hambatan. Pertama, hambatan rendahnya kesadaran masyarakat tentang zakat bagi muzaaki dan mustahik zakat. Kesadaran membayar zakat dari masyarakat menjadi salah 
satu kendala dalam pengelolaan dana zakat agar dapat berdayaguna dalam perekonomian. Sebagian kaum muslim memahami bahwa perintah zakat itu hanya diwajibkan pada bulan Ramadhan. Padahal zakat bukan sekedar ibadah yang diterapkan pada bulan Ramadhan semata, melainkan juga dapat dibayarkan pada bulan-bulan selain Ramadhan (wawancara dengan Yusrialis, Agustus, 2017).

Ide dasar zakat untuk kemaslahatan umat telah bergeser menjadi ibadah ritual semata yang dikerjakan bersamaan dengan ibadah puasa. Adanya syarat haul (satu tahun kepemilikan) menandakan bahwasanya zakat itu tidak mengenal pembayaran pada satu bulan tertentu saja. Bila kesadaran masyarakat akan pentingnya zakat bagi peningkatan kesejahteraan dan kemakmuran umat sudah semakin baik maka berimbas pada peningkatan penerimaan zakat.

Berdasarkan data yang dirilis oleh Baznas Kota Pekanbaru, jumlah mustahik zakat yang terdata adalah 1213 (seribu dua ratus tiga belas) mustahik yang tersebar di semua kecamatan di Kota Pekanbaru. Semua mustahik terdistribusi pada 5 (lima) program di atas. Rata-rata mustahik zakat adalah kelompok yang memandang bahwa zakat yang dibagikan untuk kebutuhan konsumtif, walaupun telah ditegaskan bahwa zakat yang diterima adalah zakat produktif. Beberapa mustahik zakat telah memahami bahwa zakat prduktif bertujuan untuk meningkatkan produktivitas nila tambah bagi usaha yang dilakukan oleh mustahik (wawancara dengan Yusrialis, Agustus, 2017).

Kedua, hambatan minimnya sumber daya manusia dalam pendayagunaan zakat. Pekerjaan menjadi pengelola zakat ('âmil) belum menjadi tujuan hidup atau profesi yang menjanjikan bahkan lulusan ekonomi syariah sekalipun. Lulusan ekonomi syariah lebih memilih untuk berkarir di sektor keuangan seperti perbankan atau asuransi. Sedikit orang yang memilih untuk berkarir menjadi seorang pengelola zakat.

Profesi amil zakat belum menjadi pilihan hidup karena tidak ada daya tarik berkarir di bidang itu. Padahal lembaga amil membutuhkan banyak sumber daya manusia yang berkualitas agar pengelolaan zakat dapat profesional, amanah dan akuntabel. Karir seorang amil mempunyai 2 (dua) aspek tidak hanya aspek materi semata namun aspek sosial. Beberapa kriteria pengelola zakat agar mampu menjadi suatu lembaga zakat yang profesional, yakni: 1) amanah; 2) manajerial skills; 3) ikhlas; 4) leadership Skills; 5) inovatif; dan 6) no profit motives.

Pengetahuan amil zakat tentang fikih zakat juga belum memadai. Pemahaman fikih zakat dari para amil masih menjadi salah satu hambatan dalam pengelolaan zakat. Fikih zakat hanya dipahami dari segi tekstual semata bukan konteksnya. Dalam penerapan zakat di masyarakat yang harus diambil adalah ide dasarnya agar dapat bermanfaat dan berguna bagi masyarakat serta dapat memberikan kemaslahatan bagi umat dan mampu menjadikan mustahiq pribadi yang mandiri. Namun bukan berarti para amil diberikan kesempatan untuk 
berijtihad dan berkreasi tanpa batas. Mereka tetap harus berusaha melakukan terobosan-terobosan baik pengelolaan zakat agar tetap sesuai dengan syariah.

Ketiga, hambatan tentang sistem informasi zakat. Baznas Kota Pekanbaru belum mempunyai atau menyusun suatu sistem informasi zakat yang terpadu antar amil. Sistem ini memungkinkan antar Baznas saling terintegrasi. Contohnya penerapan pada database muzaki dan mustahik. Sistem informasi ini tidak akan terjadi pada muzaki yang sama didekati oleh beberapa lembaga amil, atau mustahik yang sama diberi bantuan oleh beberapa lembaga amil zakat.

Sistem informasi zakat untuk mempermudah mengenali titik-titik lokasi yang telah digarap oleh suatu lembaga dan titik lokasi mana yang belum menerima bantuan. Kondisi ini dapat mencegah terjadinya lokasi pemberdayaan yang "gemuk" dan ada lokasi yang "kurus". Sistem informasi dapat mengkoordinasikan agar zakat tersebut manfaat dan pengaruhnya dapat terasa bagi peningkatan kemakmuran dan kesejahteraan masyarakat.

Untuk mengatasi hambatan dalam kontekstualisasi pendayagunaan zakat, Baznas Kota Pekanbaru melakukan beberapa upaya sebagai berikut: Pertama, hambatan tentang rendahnya kesadaran masyarakat terutama muzaki dan mustahik zakat dapat diatasi dengan peningkatan pendampingan terhadap mustahik yang mendapat bantuan dana zakat. Kesadaran masyarakat dalam berzakat bagi muzaki dan pemahaman mustahik zakat secara parsial harus diatasi dengan peningkatan dengan sosialisasi bagi muzaki dan mustahik zakat terkait dengan pemahaman fikih zakat secara benar berdasarkan hukum Islam.

Kedua, hambatan tentang minimnya sumber daya manusia yang berkualitas dapat diatasi dengan program peningkatan sumber daya manusia (SDM) pengelola zakat. Program itu dapat berupa pelatihan Manajerial Skills dan Leadership Skills. Berdasarkan program itu, pengelola zakat (amil) menjadi lebih optimal. Di sisi lain, terkait dengan pemahaman fikih zakat bagi amil yang belum memadai, dapat diatasi dengan meningkatkan pemahaman agama yang lebih kontekstual. Mereka tetap harus berusaha melakukan terobosan-terobosan baik pengelolaan zakat agar tetap sesuai dengan syariah.

Ketiga, hambatan tentang sistem informasi zakat yang belum memadai berakibat data base mustahik dan muzaki belum terintegrasi, dapat diatasi dengan pembaruan sistem informasi pengelolaan zakat yang terintegrasi, sehingga seluruh data muzaki dan mustahik zakat terdapat dalam 1 (satu) sistem yang memadai.

Baznas Kota Pekanbaru belum mempunyai sistem informasi zakat yang terpadu. Sistem ini memungkinkan antarBaznas saling terintegrasi. Contohnya penerapan pada data base muzaki dan mustahik. Sistem informasi ini tidak akan menjadikan muzaki yang sama dikelola oleh beberapa lembaga amil, atau mustahik yang sama diberi bantuan oleh beberapa lembaga amil zakat. 
Pengembangan sistem informasi ini dapat mempermudah pengelolaan pendayagunaan zakat, karena data telah terintegrasi dalam 1 (satu) sistem. Seorang muzaki dapat mengetahui kondisi terkini pengelolaan zakat dan para amil zakat dapat lebih mudah dalam memonitoring dan evaluasi pemberdayaan mustahik zakat.

\section{KESIMPULAN}

Berdasarkan analisis dalam pembahasan di atas, studi ini dapat disimpulkan sebagai berikut:

1. Kontekstualisasi pendayagunaan zakat di Baznas Kota Pekanbaru merupakan ijtihad yang dilakukan oleh amil zakat dalam upaya peningkatan kesejahteraan mustahik zakat. Ijtihad dalam pemberdayaan ini sebagai wujud nyata merubah status mustahik zakat menjadi muzaki. Pasal 27 Ayat (1) dan Ayat (2) Undang-Undang Nomor 23 Tahun 2011 tentang Pengelolaan Zakat tidak menyebutkan secara tegas model, pola, dan mekanisme yang tepat terkait pendayagunaan zakat dalam pengertian pemberdayaan, sehingga ijtihad kontekstualisasi yang dilakukan oleh Baznas Kota Pekanbaru sangat mungkin berbeda dengan pola pendayagunaan zakat di daerah lain.

2. Upaya kontekstualisasi merupakan upaya merubah pola pikir mustahik zakat dari konsumtif menjadi produktif sesuai dengan tujuan substansi zakat. Perubahan pola pikir mustahik zakat diikuti dengan semangat merubah prilaku menjadi produktif sebagai bagian dari upaya kontekstualisasi di Baznas Kota Pekanbaru. Dalam pandangan penulis, upaya ini harus dikuti dengan pola-pola pemberdayaan masyarakat yang tepat guna dan tepat sasaran. Upaya kontekstualisasi harus memiliki peta jalan (roadmap) sebagai panduan pelaksanaan pendayagunaan zakat. Strategi Baznas Kota Pekanbaru dalam melaksanakan upaya di atas dengan melakukan pengembangan komunitas berbasis zakat atau Zakat Community Development. Sebagai upaya awal, program ini akan difokuskan di Kecamatan Rumbai Pesisir Kota Pekanbaru. Berdasarkan keterangan Yusrialis, Kepala Pelaksana Badan Amil Zakat Nasional (Baznas) Kota Pekanbaru menyatakan bahwa Program ZCD diprioritaskan di Kecamatan Rumbai Pesisir. Hasil evalusi terhadap program pemberdayaan selama ini menunjukkan bahwa mustahik zakat di Kecamatan Rumbai lebih dapat diberdayakan dibandingkan dengan mustahik zakat di kecamatan lain di Kota Pekanbaru. Kecamatan Rumbai Pesisir ditetapkan sebagai pilot project (proyek percontohan).

3. Hambatan dan upaya yang harus dilakukan dalam mengatasi hambatan tersebut di antaranya, pertama, hambatan rendahnya kesadaran masyarakat dalam berzakat bagi muzaki dan pemahaman mustahik zakat secara parsial harus diatasi dengan peningkatan dengan sosialisasi bagi muzaki dan mustahik zakat terkait dengan pemahaman fikih zakat secara benar berdasarkan hukum Islam. Kedua, hambatan tentang minimnya sumber daya manusia yang berkualitas harus diatasi dengan adanya peningkatan kualitas pemahaman fikih zakat amil bagi amil zakat dan tata kelola pendayagunaan dan pemberdayaan zakat. Ketiga, hambatan tentang sistem informasi zakat yang belum memadai berakibat data base mustahik dan muzaki belum terintegrasi, harus diatasi dengan pembaruan sistem informasi pengelolaan 
zakat yang terintegrasi, sehingga seluruh data muzaki dan mustahik zakat terdapat dalam 1 (satu) sistem yang memadai.

\section{DAFTAR PUSTAKA}

Miftah, A.A. (2008). Pembaharuan Zakat Untuk Pengentasan Kemiskinan di Indoensia. Jurnal Innovatio, 7(14).

Pribadi, Ancas Sulchantifa Pribadi (2006). Pelaksanaan Pengelolaan Zakat Undang-Undang No. 38 Tahun 1999 tentang Pengelolaan Zakat. Semarang: Universitas Diponegoro.

Hikam, Dail (2008). Pendayagunaan Zakat Di Indonesia: Studi Kasus Pada BAZDA DKI Jakarta. Jakarta: UIN Syarif Hidayatullah.

Hafidhuddin, Didin (2007). Agar Harta Berkah dan Bertambah. Jakarta: Gema Insani Press. (2007). Agar Harta Berkah dan Bertambah. Jakarta: Gema Insani Press.

Syauqi Beik, Irfan dan Tsani, Tiara (2012). Menurunkan Kemiskinan Melalui Pendayagunaan Zakat. Iqtishodia Jurnal Ekonomi Islam Republika.

Laporan Tahunan Badan Amil Zakat Nasional (Baznas) Kota Pekanbaru Tahun 2015. Mas'udi, Masdar Farid (1993). Agama Keadilan: Risalah Zakat (Pajak) Dalam Islam. Jakarta: Pustaka Firdaus.

Zahrah, Muhammad Abu Zahrah (2001). Penerapan Zakat Dalam Dunia Modern. Jakarta: Pustaka Dian.

Galuh, Sabda Andika Galuh (2012). Pelaksanaan Zakat Profesi Pegawai Negeri Sipil di Kantor Unit Pengembangan Latihan Kegiatan Belajar Provinsi Kalba. Jurnal Gloria Yuris, 1 (1).

Idris, Safwan (1999). "ZIS Sebagai Media Pembebasan dan Pemberdayaan", dalam Hasil Rumusan Musyawarah Kerja Nasional II Lembaga Pengelola ZIS, di Batam 15-17 Ramadan 1420 H. Jakarta: Forum Zakat.

Permono, Sjechul Hadi (1995). Pendayagunaan Zakat Dalam Rangka Pembangunan Nasional. Jakarta: Pustaka Firdaus. . Spektrum Zakat Dalam Membangun Ekonomi Kerakyatan. Jakarta: Zikrul Hakim.

Qaradhawi, Yusuf (1997). Likay Tanjaha Muassasata al-Zakâh fi Tathbîqi alMu'akhir, terj. Asmuni Sholihin, Zamaksyari. Jakarta: Media Dakwah. (1994). Fiqh al-Zakâh. Juz I-II. Bairût: Muassasah al-Risâlah. 